\title{
EFEKTIFITAS ATRAKTAN ALAMI DENGAN TAMBAHAN LIMBAH CAIR PABRIK TAHU TERHADAP RAYAP TANAH (Coptotermes $s p$ )
}

\author{
(Effectiveness of bio-attractant with additional of liquid waste from tofu factory against \\ subterranean termite Coptotermes sp)
}

\author{
Wulandari Y, Sofwan Anwari \\ Fakultas Kehutanan Universitas Tanjungpura, Jalan Imam Bonjol Pontianak 78124 \\ Email : wulandariy111293@gmail.com
}

\begin{abstract}
Efforts to reduce losses caused by termite attacks are require an effective and environmentally friendly method. One of the environmentally friendly termite controls can be used such as bait system using natural attractants. Plants that can be used as natural attractants include eucalyptus leaves (Melaleuca leucadendra). The purpose of the study were to evaluate the effectiveness of the mixture of eucalyptus leaves, waste paper and liquid waste from tofu factory which has potential as natural attractants to control of termites and to determine the most effective composition of eucalyptus leaf, waste paper and liquid waste from tofu factory as a bio-atactant. Testing was done in two methods: No-choice test and two choice test, using five compositions of eucalyptus leaves: waste paper i.e 0\%: 100\% (as a control), 20\%: 80, 40\%: 60\%, 60\%: $40 \%$, and 80\%: 20\%. The results showed that the mixture of eucalyptus leaves and waste paper with composition of 40\%: $60 \%$ can be used as a bio-attractant against termites (Coptotermes sp).

Key words: bio-attractant, eucalyptus leaves, waste paper, Coptotermes sp.
\end{abstract}

\section{PENDAHULUAN}

Rayap merupakan serangga kecil berwarna putih pemakan selulosa yang sangat berbahaya bagi bangunan dengan bahan-bahan yang mengandung selulosa seperti kayu dan produk turunan kayu yaitu : papan partikel, papan serat, blockboard dan laminated board (Hasan, 1986). Di Indonesia, rayap yang paling banyak menimbulkan kerugian adalah rayap tanah (subterranean termites) famili Rhinotermitidae, terutama genus Coptotermes dan Schedorhinotermes (Tarumingkeng, 2001).

Upaya mengurangi kerugian yang ditimbulkan akibat serangan rayap, diperlukan pengendalian untuk menekan populasi dan serangan rayap.
Pengendalian rayap sebagai serangga perusak memerlukan suatu metode yang efektif dan ramah lingkungan

Selama ini aktraktan yang banyak digunakan adalah atraktan sintetis seperti merek dagang Petrogenol 800L dan sudah beredar dipasaran tetapi harganya cukup mahal yaitu mencapai Rp. 5.750 per $5 \mathrm{ml}$ atau Rp 1.150.000,per liter selain harganya mahal, atraktan sintesis di khawatirkan memiliki dampak terhadap lingkungan. Oleh karena itu salah satu upaya untuk mendapatkan atraktan dengan biaya yang relatif murah dan ramah lingkungan adalah dengan membuat atraktan alami. Salah satu jenis tanaman yang ramah lingkungan dan dapat 
digunakan sebagai bahan atraktan alami antara lain daun kayu putih.

$$
\text { Indrayani et al., }
$$
menyatakan bahwa ekstrak daun kayu putih (Melaleucaleucadendra L.) memiliki tingkat aktraktif sebesar $80 \%$ pada konsentrasi $1 \%$, lebih tinggi dibanding ekstrak daun cengkeh $40 \%$, daun kemangi $60 \%$, daun kayu manis $53 \%$ dan daun salam $46.67 \%$. Selain daun kayu putih, bahan alami lain yang memiliki potensi sebagai atraktan adalah limbah air tahu atau air rebusan kedelai.

Penggunaan umpan berupa campuran limbah koran dan air rebusan kedelai telah diteliti oleh Muin et al., (2014) yang hasilnya adalah komposisi bahan atraktan yang dapat mengakselerasi aktifitas biologis rayap. Berdasarkan uraian di atas peneitian ini bertujuan untuk mengetahui efektifitas dan komposisi optimal campuran daun kayu putih (M.leucadendra), limbah kertas HVS dan limbah cair pabrik tahu yang efektif digunakan sebagai bioatraktan terhadap rayap tanah (Coptotermes sp).

\section{METODOLOGI PENELITIAN}

Penelitian dilaksanakan di Laboratorium Teknologi Kayu Fakultas Kehutanan Universitas Tanjungpura Pontianak. Bahan yang digunakan dalam penelitian ini adalah daun kayu putih, limbah kertas HVS, limbah cair pabrik tahu, rayap, aquades, alkohol $70 \%$, pasir. Alat yang digunakan dalam penelitian ini meliputi timbangan analitik, ember, kain hitam, blender, gelas plastik, box plastik, gunting seng, seng, oven, pinset, soft pinset, desikator, autoklaf, cawan petri, higrothermometer, aluminium-foil, kertas label, tissue, kasa plastik, sarung tangan, kapas, plastic klip.

\section{ProsedurPenelitian}

Persiapan dan Pemeliharaan Rayap

Koloni rayap tanah (Coptotermes sp) diambil dari pohon karet yang terserang rayap yang berasal dari Kecamatan Ambawang Kabupaten Kubu Raya. Bagian pohon yang terserang rayap tersebut dipotong menjadi beberapa bagian kemudian disimpan di dalam ember tempat pemeliharaan rayap. Ember yang digunakan sebagai tempat pemeliharaan rayap dimasukkan lagi kedalam baskom yang telah berisi air. Setelah itu ember ditutup dengan kain berwarna hitam dan disimpan dalam tempat gelap. Koloni rayap selanjutnya dipelihara dengan kelembaban udara sekitar 70-80\% dengan suhu ruangan selama \pm satu bulan sebelum digunakan.

Persiapan Kertas HVS

Kertas HVS yang digunakan dalam penelitian ini adalah kertas bekas atau yang sudah tidak digunakan lagi. Limbah kertas HVS dikumpulkan lalu dipotong-potong kecil,direndam dengan aquades selama 24 jam kemudian diblender untuk memperoleh bahan berupa serat-serat yang lebih halus.

Persiapan daun kayu putih

Daun kayu putih diambil dijalan MT. Haryono kota Pontianak. Daun kayu putih dikering udarakan selama \pm 10 hari, dihampar dalam ruangan hingga daun benar-benar kering 
udara. Selanjutnya daun dimasukkan kedalam plastik yang kedap udara. Daun kayu putih yang sudah kering tersebutdirendam dengan aquades kemudian dihancurkan dengan menggunakan blender hingga halus.

Persiapan limbah cair pabrik tahu

Limbahcair pabrik tahu yang diperoleh dari rumah produksi pembuatan tahu di Singkawang. Limbah cair pabrik tahu disaring, lalu disimpan dalam kulkas agar tidak terjadi fermentasi berkelanjutan.

\section{Pembuatan bahan umpan}

Umpan (sampel) dicetak dengan ukuran 2(p) x 2(l) x 1(t) cm dengan target kerapatan $0,75 \mathrm{~g} / \mathrm{cm}^{3}$. Perhitungan keperluan bahan untuk pembuatan bahan umpan dari perbandingan daun kayu putih dan kertas HVS dengan masing-masing komposisi adalah sebagai berikut, $0 \%$ : 100\%, 20\% : 80\%, 40\% : 60\%, 60\% : $40 \%, 80 \%: 20 \%$. Masing-masing komposisi tersebut, sampel dibentuk dengan menggunakan cetakan seng ukuran $2 \times 2 \times 1 \mathrm{~cm}$. Setelah dicetak sampel dikering udarakan selama 24 jam. Kemudian dioven dengan suhu 40 $\pm 2^{0} \mathrm{C}$ selama 48 jam agar umpan menjadi lebih kering dan terhindar dari jamur yang dapat merusak umpan. Setelah itu umpan dimasukkan kedalam desikator selama 30 menit dan ditimbangan untuk mengetahui berat awal.
Pengujian dilakukan dengan menggunakan metode Ohmura et al(2000) yang telah dimodifikasi. Pengujian dilakukan dengan dua cara yaitu no choice test dan two-choice test. 1. Pengujian dengan Metode Tanpa Pilihan(No Choice Test)

Pengujian efektifitas campuran daun kayu putih, limbah kertas HVS dan limbah air tahu terhadap rayap mengikuti prosedur Ohmura (1997). Gelas uji berukuran diameter $6 \mathrm{~cm}$ tinggi $6 \mathrm{~cm}$ diisi pasir sebanyak 13 gram atau setinggi $1 \mathrm{~cm}$. Pasir yang digunakan untuk pengujian merupakan pasir steril yang telah di autoclave selama 1 jam kemudian dioven selama 24 jam dengan suhu $60 \pm 2^{0}$ C. Pengovenan pasir bertujuan agar pasir yang digunakan lebih kering. Kemudian dibahas dengan aquades sebanyak $3 \mathrm{ml}$ atau $20 \%$ dari berat pasir. Kedalam gelas yang berisi pasir diberi alas kasa plastik. Dimasukkan satu sampel uji yang telah ditetesi dengan limbah cair pabrik tahu sebanyak $60 \%$ dari berat kering sampel. Masing-masing gelas uji dimasukkan 50 ekor rayap kasta pekerja dan 5 ekor rayap prajurit. Gelas-gelas uji kemudian ditutup menggunakan kain hitam, lalu dimasukkan kedalam wadah plastik yang berukuran besar yang telah diberi kapas basah, pada kelembaban \pm $76 \%-80 \%$ dan suhu $\pm 26 \%-27 \%$. Gambar (1) 


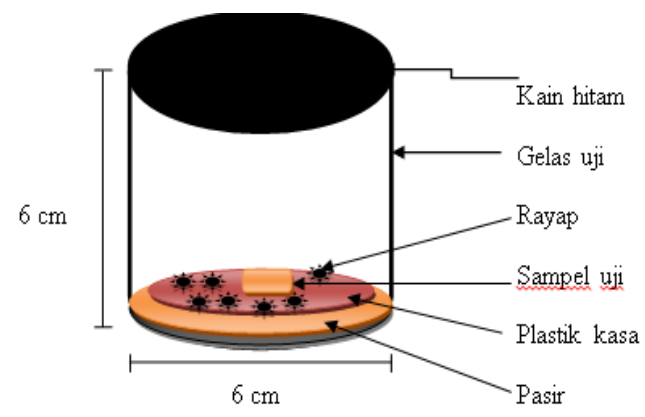

Gambar1.Pengujian No Choice Test)

2. Pengujian dengan Metode Dua Pilihan (TwoChoice Test)

Two Choice Test merupakan metode pengujian dimana rayap diberikan dua pilihan yaitu sampel uji yang terbuat dari $100 \%$ kertas sebagai kontrol dan sampel uji yang terbuat dari campuran kertas HVS dan daun kayu putih.Gelas uji yang digunakan berukuran diameter $11 \mathrm{~cm}$ tinggi $6 \mathrm{~cm}$ diisi pasir steril sebanyak 67 gram kemudian dibasahi dengan aquades sebanyak $13 \mathrm{ml}$ atau $20 \%$ dari berat pasir, Kedalam gelas yang berisi pasir diberi alas kasa plastik. Kemudian dimasukan dua sampel uji yaitu yang terbuat dari $100 \%$ kertas HVS sebagai kontrol dan sampel uji yang terbuat dari campuran daun kayu putih dan kertas HVS yang telah di tetesi dengan limbah cair pabrik tahu sebanyak $60 \%$ dari berat kering sampel. Masing-masing gelas uji dimasukkan 50 ekor rayap kasta pekerja dan 5 ekor rayap prajurit. Tujuan menggunakan 5 ekor rayap prajurit adalah agar rayap pekerja tersebut merasa aman. Gelas-gelas uji kemudian ditutup menggunakan kain hitam, lalu dimasukkan kedalam wadah plastik yang berukuran besar yang telah diberi kapas basah. Lamanya waktu pengujian dan cara pengujian pada Two Choice Testjuga sama dengan noTwoChoice Test. Gambar

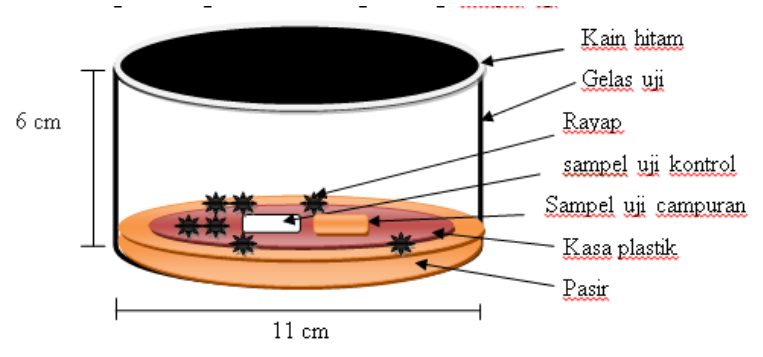

Gambar 2. Pengujian dengan Metode DuaPilihanTwo Choice Test

Setelah 14 hari pengujian sampel uji dibersihkan dari kotoran lalu dimasukan kedalam oven pada suhu $40^{\circ} \mathrm{C}$ selama 48 jam. Setelah 48 jam sampel uji dikeluarkan selanjutnya dimasukan ke dalam desikator selama
15 menit kemudian ditimbang untuk mengetahui berat akhir sampel uji.

\section{Variabel Pengamatan}

Data yang dikumpulkan dalam penelitian ini adalah kehilangan berat dan mortalitas rayap seperti diuraikan sebagai berikut : 


\section{Kehilangan Berat}

Kehilangan berat dihitung dengan rumus sebagai berikut Sornnuwat et al.,(1995), :

$A=\frac{\mathrm{W} 1-\mathrm{W} 2}{\mathrm{~W} 1} \times 100 \%$

Dimana:

A $=$ Persentase kehilangan berat $(\%)$

$\mathrm{W} 1$ =Berat umpan awal sebelum pengumpanan $(\mathrm{g})$

W2 =Berat umpan setelah pengumpanan terhadap rayap $(\mathrm{g})$

2. Mortalitas rayap

Parameter yang diamati dalam penelitian ini yaitu mortalitas rayap dengan pengecekan 2 minggu setelah masa pengujian dilakukan. Penentuan nilai mortalitas dilakukan dengan rumus yang dikemukan oleh Sornnuwatet al.,(1995) yakni sebagai berikut :
$M(\%)=\frac{N 2}{N 1} \times 100 \%$

Dimana :

$M \quad$ = Mortalitas rayap dalam persen

$(\%)$

$\mathrm{N} 1=$ Jumlah rayap awal (ekor)

$\mathrm{N} 2=$ Jumlah rayap yang mati setelah pengumpanan (ekor)

\section{HASILPENELITIAN}

Pengujian Tanpa Pilihan (No Choice

Test)

Kehilangan Berat sampel uji

Hasil pengamatan yang dilakukan menunjukkan bahwa sampel uji mengalami kehilangan berat yang berbeda-beda. Nilai rata-rata kehilangan berat sampel uji setelah 2 minggu pengujian, disajikan dalam bentuk diagram yang dilihat pada Gambar 3.

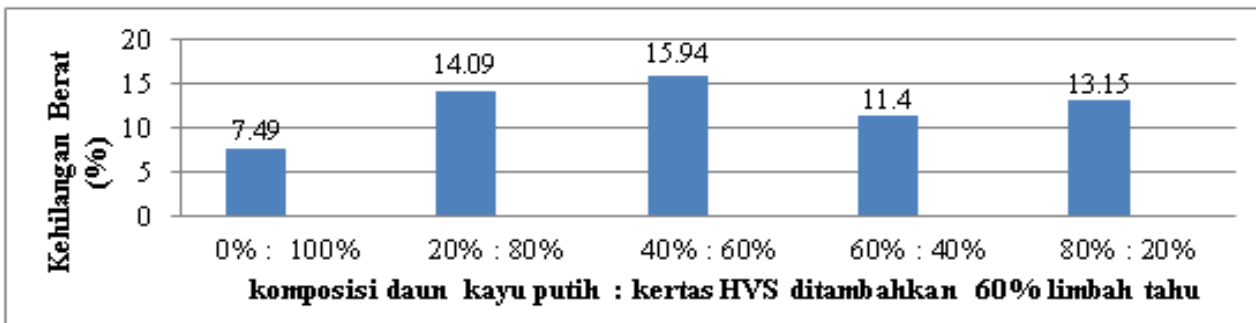

Gambar 3. Rerata kehilangan berat sampel uji

Gambar 3 menujukan kehilangan berat sampel uji tertinggi pada komposisi daun kayu putih $40 \%$ dan kertas HVS 60\% dengan kehilangan berat sebesar $15,94 \%$. Sedangkan Tabel 1. Hasil Analisis Keragaman Kehilangan Berat Sampel Uji

\begin{tabular}{lcccccc}
\hline \multicolumn{1}{c}{$\begin{array}{c}\text { Sumber } \\
\text { Keragaman }\end{array}$} & $\begin{array}{c}\text { Derajat } \\
\text { Bebas }\end{array}$ & $\begin{array}{c}\text { Jumlah } \\
\text { Kuadrat }\end{array}$ & $\begin{array}{c}\text { Kuadrat } \\
\text { Tengah }\end{array}$ & \multirow{2}{*}{ F Hitung } & \multicolumn{2}{c}{ F.TABEL } \\
\hline Perlakuan & 4 & 123,09 & 30,77 & $74,03^{* *}$ & 3,48 & 5,99 \\
Galat & 10 & 4,16 & 0,42 & & & \\
\hline Total & 14 & 127,25 & & & & \\
\hline
\end{tabular}

Keterangan (**) : Berpengaruh Sangat Nyata pengurangan berat terendah ditunjukan oleh komposisi daun kayu putih $0 \%$ dan kertas HVS $100 \%$ kehilangan berat sebesar $7,49 \%$. 
Hasil analisis keragaman kehilangan berat sampel uji pada pengujian no choice testyang ditampilkan dalam Tabel 1, menunjukkan bahwa perlakuan yang diberikan kepada rayap berpengaruh sangat nyata terhadap kehilangan berat sampel.
Pengujian Dua Pilihan (Two Choice Test)

Hasil pengamatan kehilangan berat twochoice test pada sampel uji berbeda dengan dengan hasil pengamatan no choice test. Hasil pengamatan pengujian two choice testtersebut dapat dilihat pada Gambar 4.

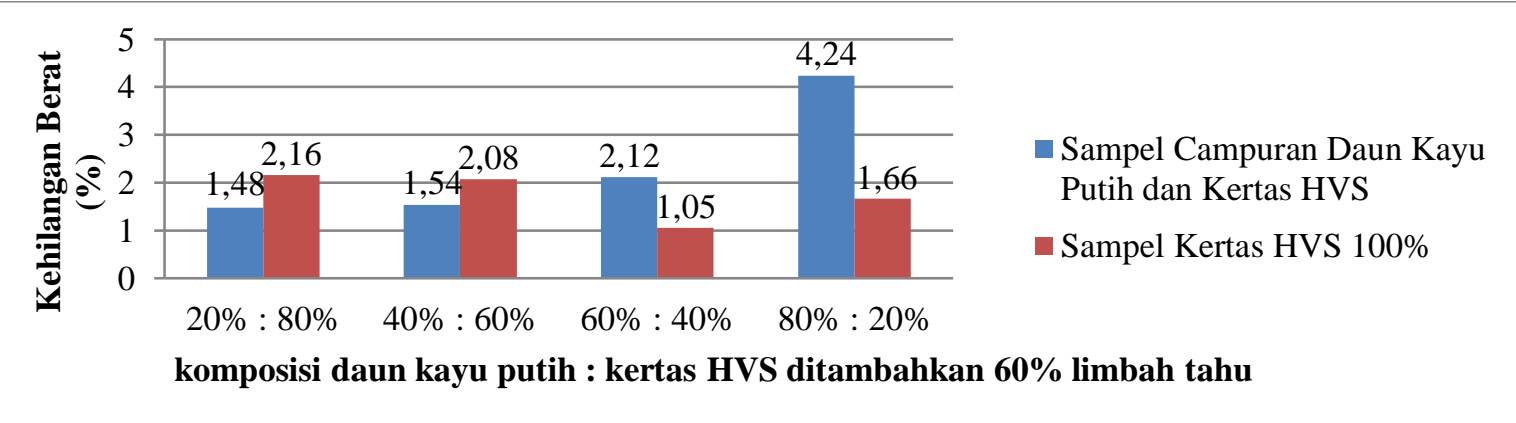

Gambar 4. Kehilangan berat sampel uji pada berbagai komposisi dan kontrol

Gambar 4 menunjukkan persentase kehilangan berat sampel uji tertinggi ditunjukkan oleh sampel yang memiliki komposisi campuran daun kayu putih $80 \%$ dan kertas HVS $20 \%$ dengan kehilangan berat sebesar 4,24\%. Sedangkan nilai terendah dihasilkan sampel yang memiliki komposisi campuran daun kayu putih $20 \%$ dan kertas HVS $80 \%$ dengan kehilangan berat sebesar $1,48 \%$. Hasil perhitungan analisis keragaman terhadap kehilangan berat dapat dilihat pada Tabel 2.

Tabel 1. Hasil Analisis Keragaman Kehilangan Berat Sampel Uji

\begin{tabular}{lcccccc}
\hline \multicolumn{1}{c}{$\begin{array}{c}\text { Sumber } \\
\text { Keragaman }\end{array}$} & $\begin{array}{c}\text { Derajat } \\
\text { Bebas }\end{array}$ & $\begin{array}{c}\text { Jumlah } \\
\text { Kuadrat }\end{array}$ & $\begin{array}{c}\text { Kuadrat } \\
\text { Tengah }\end{array}$ & F.HITUNG & \multicolumn{2}{c}{ F Tabel } \\
\hline Perlakuan & 3 & 15,11 & 5,04 & $18,99 * *$ & 4,07 & 7,59 \\
Galat & 8 & 2,12 & 0,27 & & & \\
\hline Total & 11 & 17,23 & & & & \\
\hline
\end{tabular}

Keterangan $(* *)$ : Berpengaruh Sangat Nyata

Hasil analisis keragaman yang disajikan dalam Tabel 2 menunjukkan bahwa komposisi perbandingan bahan berpengaruh sasngat nyata terhadap kehilangan berat umpan, $\mathrm{F}$ hitung memiliki nilai yang lebih tinggi dari $\mathrm{F}$ tabel pada taraf $5 \%$.

\section{PEMBAHASAN}

\section{Kehilangan Berat}

Diketahui bahwa aktifitas makan rayap adalah mencicipi makanan yang diberikan dengan jalan menggigit bagian permukaan sampel uji. Bila bagian tersebut tidak cocok rayap akan beralih kebagian lainnya sampai akhirnya rayap menemukan bagian yang sesuai dan disukai sebagai makanan. Hasil pengamatan menunjukkan bahwa semua 
perlakuan sampel uji dapat dikonsumsi oleh rayap karena pada setiap perlakuan mengalami pengurangan berat. Daun kayu putih, limbah kertas HVS dan limbah cair pabrik tahu merupakan bahan-bahan yang disukai oleh rayap. Atraktan yang berasal dari tanaman daun kayu putih (Melaleuca leucadendron L.) memiliki kandungan metil eugenol yang diduga mampu mengundang rayap untuk memakan sampel uji. Hal ini sejalan dengan pendapat Kardinan (2007) mengatakan bahwa metil eugenol $\left(\mathrm{C}_{12} \mathrm{H}_{24} \mathrm{O}_{8}\right)$ adalah bahan semio chemicals merupakan atraktan lalat buah yang dapat merangsang olfactory (alat sensor) serangga. Hasil ini diperkuat oleh Simbolon (2015) yang mengatakan bahwa atraktan daun kayu putih mampu mengundang rayap dengan jumlah perpindahan rayap yaitu 43 ekor pengamatan dilakukan selama 8 jam di bandingkan atraktan dari daun cengkel, daun kemangi, daun kayu manis dan daun salam. Selain menggunakan daun kayu putih (M. leucadendron) penelitian ini juga menggunakan kertas HVS yang mengandung selulosa yang merupakan makanan yang disukai rayap.

Hal ini sesuai dengan pernyataan yang dikemukakan oleh Tarumingkeng (2001) bahwa makanan utama rayap adalah kayu atau bahan yang terutama terdiri atas selulosa. Hal ini semakin dipertegas dengan hasil penelitian Muin et al., (2014) yang memperlihatkan bahwa campuran kayu pinus terdegradasi dengan limbah kertas HVS dan dengan limbah karton dan kertas koran dapat diformulasikan menjadi umpan yang bersifat penarik (attractant) terhadap rayap. Demi memenuhi kebutuhan makan rayap juga membutuhkan protein untuk kelangsungan hidupnya. Hal ini sesuai dengan pernyataan Yoshimura (1995) yang menyatakan bahwa zat lain seperti protein juga diperlukan oleh rayap untuk pertumbuhannya serta sebagai energi untuk bertelur. Pernyataan ini mendukung penggunaan limbah cair pabrik tahu yang ditambahkan pada umpan menunjukkan kehilangan berat yang tinggi. Hal ini sependapat dengan Mahmud (1990) yang menyatakan bahan baku tahu adalah kedelai yang tersusun dari komponenkomponen yang berupa: protein berkisar 40-60\%, karbohidrat berkisar 25-50\%, lemak berkisar $8-12 \%$, dan sisanya berupa kalsium, besi, fosfor, dan vitamin. Protein merupakan komponen yang dominan di dalam tahu. Komponen-komponen yang dicampurkan dalam umpan rayap tersebut menjadi pemicu utama rayap untuk memakan umpan yang diberikan, dan menyebabkan kehilangan berat pada umpan.

Hasil penelitian dengan menggunakan dua pengujian yaitu No Choice Test dan Two Choice Test menunjukkan hasil yang berbeda. Kehilangan berat tertinggi pada pengujian No Choice Test yaitu pada perlakuan campuran daun kayu putih $40 \%$ dan kertas HVS 60\%. Sedangkan pengujian Two Choice Test yaitu pada perlakuan campuran daun kayu putih $80 \%$ dan kertas HVS 20\%. Hal ini dapat diartikan bahwa komposisi campuran daun kayu putih $40 \%$ dan kertas HVS 60\% sudah dapat digunakan untuk mengundang/menarik rayap memakan sampel uji. 
Mortalitas Rayap

Pengujian Tanpa Pilihan (No Choice Test)

Mortalitas rayap pada setiap komposisi sampel uji memiliki nilai yang berbeda-beda. Nilai rata-rata mortalitas rayap disajikan dalam bentuk diagram yang dapat dilihat pada Gambar 5.

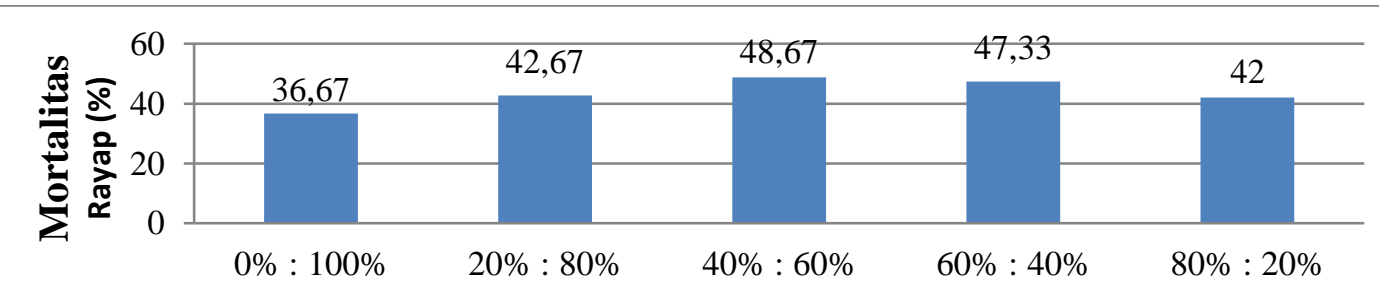

komposisi daun kayu putih : kertas HVS ditambahkan $60 \%$ limbah tahu

Gambar 5. Mortalitas RayapCoptotermes sp.

Gambar 5 dapat dilihat persentase

Sedangkan persentase mortalitas rayap rata-rata mortalitas rayap tertinggi pada komposisi daun kayu putih $40 \%$ dan kertas HVS $60 \%$ yaitu $48,67 \%$. terendah ditunjukan oleh sampel uji komposisi daun kayu putih $0 \%$ dan

Tabel 3. Hasil Analisis Keragaman Mortalitas Rayap Coptotermes sp.

\begin{tabular}{|c|c|c|c|c|c|c|}
\hline \multirow{2}{*}{$\begin{array}{c}\text { Sumber } \\
\text { keragaman }\end{array}$} & \multirow{2}{*}{$\begin{array}{c}\text { Derajat } \\
\text { Bebas }\end{array}$} & \multirow{2}{*}{$\begin{array}{l}\text { Jumlah } \\
\text { Kuadrat }\end{array}$} & \multirow{2}{*}{$\begin{array}{l}\text { Kuadrat } \\
\text { Tengah }\end{array}$} & \multirow{2}{*}{ FHitung } & \multicolumn{2}{|c|}{ F.Tabel } \\
\hline & & & & & $5 \%$ & $1 \%$ \\
\hline Perlakuan & 4 & 273,07 & 68,27 & $2,23^{\text {tn }}$ & 3,48 & 5,99 \\
\hline Galat & 10 & 306,67 & 30,67 & & & \\
\hline Total & 14 & 579,73 & & & & \\
\hline
\end{tabular}

Keterangan (tn) : Tidak Berpengaruh Nyata

Hasil analisis keragaman mortalitas rayap yang disajikan dalam Tabel 3, menunjukkan bahwa perlakuan yang diberikan kepada rayap tidak berpengaruh nyata terhadap mortalitas rayap.

Mortalitas rayap

Pengujian Dua Pilihan (Two Choice Test)

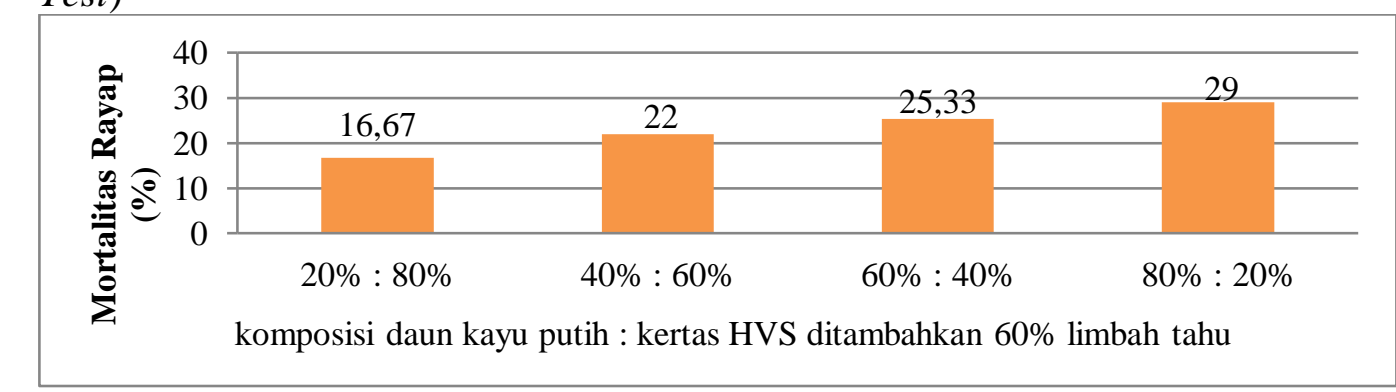

Gambar 6. Rerata Mortalitas Rayap
Mortalitas rayap pada pengujian two choice test mempunyai tingkatan yang berbeda. Perhitungan mortalitas rayap pada pengujian two choice test sama dengan perhitungan no choice test. Hasil rata- rata mortalitas disajikan dalam bentuk diagram, dapat dilihat pada Gambar 6. 
Hasil pengamatan menunjukkan bahwa persentase mortalitas rayap tertinggi ditunjukan oleh sampel uji yang perlakuan daun kayu putih $80 \%$ dan kertas HVS 20\% yaitu $29 \%$.
Sedangkan persentase mortalitas rayap terendah ditunjukan oleh sampel uji perlakuan daun kayu putih $20 \%$ dan kertas HVS $80 \%$ yaitu $16,67 \%$.

Tabel 4. Hasil Analisis Keragaman Mortalitas Rayap Coptotermes sp.

\begin{tabular}{lcccccc}
\hline \multicolumn{1}{c}{ Sumber } & Derajat & Jumlah & Kuadrat & \multirow{2}{*}{ F.HITUNG } & \multicolumn{2}{c}{ F Tabel } \\
\cline { 6 - 7 } Keragaman & Bebas & Kuadrat & Tengah & F.HI & $1 \%$ \\
\hline Perlakuan & 3 & 258.67 & 86,22 & $3,92^{\text {th }}$ & 4,07 & 7,59 \\
Galat & 8 & 176 & 22 & & & \\
\hline Total & 11 & 434,67 & & & & \\
\hline
\end{tabular}

Keterangan $\left({ }^{\mathrm{tn}}\right)$ : Tidak Nyata

Hasil analisis keragaman mortalitas rayap menunjukkan bahwa pengujian yang dilakukan tidak nyata terhadap mortalitas rayap, dimana $\mathrm{F}$ hitungnya lebih rendah dari $\mathrm{F}$ tabel pada taraf kepercayaan $5 \%$. sehingga tidak diperlukan uji lanjut.

\section{Mortalitas Rayap}

Jumlah rayap yang mati setelah pengumpanan menjadi parameter sangat penting dalam melihat keefektifan bioatraktan tersebut dalam metode pengumpanan dengan menggunakan pengujian No Choice Testdan pengujian Two Choice Testselama 14 hari. Tingginya tingkat mortalitas pada perlakuan inididuga banyaknya rayap mengkonsumsi sampel uji yang menyebabkan kemampuan minyak atsiri mematikan rayap selama proses pengujian dilakukan. Kandungan minyak atsiri terdapat bioaktif dari golongan terpenoid yaitu sesquiterpen. Sastrodiharjdo (1999) juga mengatakan zat ekstraktif yang digunakan dapat berpengaruh terhadap kematian rayap dan serangga lainnya yaitu sebagai penghambat sintesis protein, khususnya dari kelompok tanin, stilbena, alkaloid, dan resin, sedangkan kelompok terpenoid dapat merusak fungsi sel rayap yang pada akhirnya menghambat proses ganti kulit rayap. Hal ini sejalan dengan pendapat Khabibi (2011), menyebutkan bahwa komponen utama penyusun minyak kayu putih adalah sineol $\left(\mathrm{C}_{10} \mathrm{H}_{18} \mathrm{O}\right)$, pinene $\left(\mathrm{C}_{10} \mathrm{H}_{8}\right)$, benzaldehide $\left(\mathrm{C}_{10} \mathrm{H}_{5} \mathrm{H}_{\mathrm{O}}\right)$, limonene $\left(\mathrm{C}_{10} \mathrm{H}_{16}\right)$ dan sesquiterpentes $\left(\mathrm{C}_{15} \mathrm{H} 2_{4}\right)$. Hal ini dijelaskan oleh Harto (1998) dalam Hadi (2008), senyawa sesquiter dapat merusak system saraf pada rayap, masuknya senyawa tersebut diketahui dapat menghambat enzim asetil kolinesterase sehingga menyebabkan mortalitas rayap. Mortalitas rayap juga bisa terjadi karena tidak adanya alternatife makanan lain sehingga menyebabkan rayap yang tidak memakan umpan dan memilih untuk berpuasa lalu mati Suhesti (2003).

Hasil penelitian menunjukkan kecenderungan semakin banyak daun putih yang digunakan semakin meningkat pula mortalitas rayap. Hal ini menunjukkan bahwa minyak atsiri 
memiliki pengaruh terhadap mortalitas rayap tanah, semakin tinggi komposisi minyak atsiri yang ditambahkan pada sampel uji maka akan semakin tinggi pula tingkat mortalitas yang terjadi pada rayap. Hal ini sejalan dengan pendapatAstuthi et al.,(2012) bahwa persentase mortalitas meningkat pada konsentrasi tinggi.Penelitian ini komposisi campuran daun $80 \%$ dan kertas $20 \%$ merupakan tingkat pemakaian yang optimal dalam pengendalian rayap Copotermes $s p$ dengan nilai mortalitas mencapai $29 \%$. Nilai persentase mortalitas rayap yang tinggi dengan adanya penggunaan minyak atsiri daun kayu putih ( $M$. leucadendra) diduga disebabkan oleh interaksi kimia yang terjadi antara rayap dengan minyak atsiri. Hal ini sejalan dengan pendapat Siranon et al.,(2008) yang menyatakan minyak atsiri sebagian besar memiliki cara kerja yang menghambat sistem saraf serangga. Kemudian dipertegas Sakasegawa et al.,(2003) menyatakan minyak atsiri dari daun Melaleuleca sp menyebabkan kematian rayap dengan gejala mengalami keracunan pada sistem pernafasan.Dengan demikian campuran daun kayu putih dan limbah kertas HVS efektif dalam pengendalian rayap.

\section{Kesimpulan}

1. Pengujian dengan metode No Choice Test dan Two Choice Test efektif digunakan sebagai bioatraktan pada rayap tanah (Coptotermes sp).

2. Komposisi campuran daun kayu putih $40 \%$ dan kertas HVS 60\% sudah dapat digunakan sebagai bioatraktan terhadap rayap.

\section{Saran}

Perlu adanya penelitian lanjutan untuk menguji efektifitas bioatraktan campuran daun kayu putih ( $M$. leucadendra), limbah kertas HVS limbah cair pabrik tahu terhadap rayap tanah (Coptotermes sp) di lapangan.

\section{DAFTAR PUSTAKA}

Astuthi, M. M. M., Sumiartha, K., Susila, I.W., Wirya, G.N.A.S., dan Sudarta, I. P., 2012., Efikasi Minyak Atsiri Tanaman Cengkeh (Syzygium aromaticum (L.) Meer. \&Perry), Pala (Myristica fragrans Houtt), dan Jahe (Zingiber officinale Rosc.) Terhadap Mortalitas Ulat Bulu Gempinis Dari Famili Lymantriidae, J.Agric.Sci. And Biotechnol, 1(1):12-23.

Hadi, M., 2008, Pembuatan Kertas Anti Rayap Ramah Lingkungan dengan Memanfaatkan Ekstrak Daun Kirinyuh (Eupatorium odoratum), Laboratorium Ekologi dan Biosistematik, Jurusan Biologi FMIPA Undip, 6(2) :1218

Kardinan, A. 2007. Pengaruh Campuran Beberapa Jenis Minyak Nabati Terhadap Daya Tangkap Lalat Buah. Bul. Littro (1): $60-66$.

Dikutip

dari balittro.litbang.deptan.go.id/ind/i ma ges/stories/.../6-lalatbuah.pdf. Diakses pada tanggal 9 Januari 2012

Khabibi.2011. Pengaruh penyimpanan daun danvolume air penyuling terhadap rendemen danmutu 
minyak kayu putih. Departemen hasil hutanFakultas Kehutanan Institut Pertanian Bogor, Bogor.

Mahmud, M.K., Dewi S.S., Rossi, R.A., dan Hermana., 1990, " Komposisi Zat Gizi Pangan Indonesia Departemen kesehatan RI. ", Directorat Bina Gizi Masyarakat dan Pusa Penelitian pengembangan Gizi, Jakarta.

Muin M, Arif A, Nuraeni S. 2014. Pengembangan Sistem Kontrol Rayap untuk Produksi Biogenik dan Perbaikan Produktivitas Lahan Hutan Pendidikan Universitas Hasanuddin. http://repository.unhas.ac.id/bitstr eam/handle/ 123456789/12728/ABS.musrisal $\% 20$ muin.docx? sequence $=1$.

Diakses tanggal [9 Desember 2015].

Sakasegawa, M, Horik, Mitsuyoshi Y. 3003. Composition and antitermite activities of essensial oils from Melaleuca species. Journal of Wood Science 49 : 181 $-187$.

Sastrodiharjo, S. 1999., Arah Pembangunan dan Strategi Penggunaan Pestisida Nabati, Makalah Disajikan pada Forum Komunikasi Pemanfaatan Pestisida Nabati, Balai Penelitian Tanaman Rempah dan Obat. 9-10 November.Bogor : Balai Penelitian Tanaman Rempah dan Obat.
Simbolon RI, Indrayani Y, Husni H. 2015. Efektifitas Bioaktraktan Dari Lima Jenis Tanaman Terhadap Rayap Tanah (Coptotermes sp). Jurnal Hutan Lestari 4(1) : 40-46.

Siranon P, Ohtani Y, Ichiura H. 2008. Biological Performance of Eucalyptus camaldulensis leaf oils from Thailnad against the subterranean termites Coptotermes formosanus Shiraki. Journal of Wood Science.55: 4446.

Suhesti, E. 2003. Preferensi makanan rayap tanah Coptotermes curvignathus Holmgren (Isoptera: Rhinotermitidae) terhadap kayu pinus termodifikasi secara fisi dan hayati. Tesis Program Studi Ilmu Pengetahuan Kehutanan. Institut Pertanian Bogor. Bogor. [tidak dipublikasikan]

Tarumingkeng, R. C., 2004. Biologi dan Pengendalian Rayap Hama Banguan di Indonesia. http://tumoutou.net/dethh/5.termit e.behavior..html. (di akses 6 Februari 2013)

Yoshimura, T. 1995. Contribution of the protozoan fauna to nutritional physiology of the lower termite, Coptotermes formosanus Shiraki (Isoptera: Rhinotermitidae). Ph.D. Dissertation. University of Kyoto, Japan. 